\title{
The Problem of Legal Hermeneutic in Kenya Concerning the Entrenched Concept of "Public Participation" And the Transformative Public Sphere Reflected in Judicial Review No. 378 of 2017
}

\author{
*Dr. Peter Onyango Onyoyo, ${ }^{1}$ Justice Joel Ngugi, ${ }^{2}$ Justice John Mativo
}

\author{
${ }^{3}$ Justice George Odunga Al-Gurair
}

*Law Senior Lecturer University of Nairobi, ${ }^{1}$ Printing and Publishing Company in Dubai

${ }^{2}$ Independent Electoral and Boundary Commission (IEBC), ${ }^{3}$ The National Super Alliance (NASA)

info@assiagency.com

Abstract: Legal hermeneutics is the science that considers the study of law as interpretation and understanding. The Romans would refer to the art of law as the practice of bono et aequo or the science of good and justice. This legal research is anchored on the High Court ruling on the legality of awarding tender for printing presidential ballot papers of 2017 to Al-Gurair company printing and publication. The allegation was that the lawful procedures of tendering process were not respected by the respondent, in this case, the Independent Elections and Boundary Commission (IEBC) making the court quash the tender. The study therefore, surveys the questions of interpretation and understanding of the rule of public participation in the Republic of Kenya.

Keywords: Legal hermeneutics, public participation, constitutionalism, legal reasoning and politics.

\section{BACKGROUND OF THE STUDY}

The constitutionality ${ }^{1}$ surrounding the euphoric expression "public participation" ${ }^{2}$ has emerged for the very first time as a question of interpretation and understanding of Kenyan legal system. ${ }^{3}$ Such words as "public" and "participation" ${ }^{5}$ require legal hermeneutics and articulate understanding of the meaning of the concept by the administration action. Legal hermeneutics in its widest sense, means the science of interpretation and

application of legal rules. ${ }^{6}$ Prof. Olekzandr Merezhko ${ }^{7}$ affirms the same argumentation by alluding to law as a discipline that involves both interpretation and understanding of the law.

Francis J. Mootz in his paper entitled "The ontological basis of the legal hermeneutics: A Proposed Model of Inquiry Based on the Work of Gadamer, Habermas and Ricoeur", makes it even clearer that legal interpretation should consider exegesis ${ }^{8}$ as one of the most recommended approaches for better legal interpretation and the ${ }^{1}$ George E. Fellows, 'Constitutionalism', Maine Law Review, 1 (1908), 122.

${ }^{2}$ Kluwer Law International Journal Library Search - HeinOnline.Org' <https://vpn.uonbi.ac.ke/proxy/http/heinonline.org/HOL/LuceneS earch?terms=public+participation\&collection=kluwer\&searchtype=advanced\&typea=text\&tabfrom=\&submit=Go $>[$ accessed 12 July 2017].

${ }^{3 \prime}$ Kenya Law: The Constitution of Kenya' <http://www.kenyalaw.org/kl/index.php?id=398> [accessed 12 July 2017].

${ }^{4}$ Craig J. Calhoun, Habermas and the Public Sphere (MIT press, 1992) <https://books.google.com/books?hl=en\&lr=\&id=5F8qjMkoxZ0C\&o i=fnd\&pg=PR7\&dq=habermas+public+sphere\&ots=muxhD0ZOe9\&sig=ioANQJxp2yiowBJyR4myVKXpG4U> [accessed 14 July 2017].

${ }^{5}$ Zillur R. Khan, 'The Concept of Justice and Democracy', 2011 <http://rc37.ipsa.org/post/2011/03/29/The-Concept-of-Justice-and-Democracy> [accessed 14 July 2017].

${ }^{6}$ Legal Hermeneutics Pdf - Google Search'<https://www.google.com/\#q=legal+hermeneutics+pdf> [accessed 13 July 2017].

${ }^{7}$ Legal Hermeneutics Pdf - Google Search'.

${ }^{8}$ Legal Hermeneutics Pdf - Google Search'. 
The Problem of Legal Hermeneutic in Kenya Concerning the Entrenched Concept of "Public Participation" And the Transformative Public Sphere Reflected in Judicial Review No. 378 of 2017

understanding of proscribed existing law. The author intends to affirm that, the legal interpretation is not only based on the legal texts but also the non legal texts and other diverse social issues such as the phenomenology, conflictology, anthropology, gnoseology, semiotics, dialect, and dialogue. ${ }^{9}$

Judicial review process takes into account a range of issues concerning humanity and social realities that extend beyond the limits of positive law. Interpretation and understanding of the wordings and verbatim of the law, therefore, ought to be indispensable and condition sine qua non judicial reasoning.

For instance, deducing the same thought from the non legal disciplines, there is no public project in modern democratic systems that should take place without meaningful involvement of the public or participation of the community affected by it. ${ }^{10}$

It is one thing to speak about public involvement and it is another issue all together to interpret it verbatim within the law. The aim and purpose for legal hermeneutics is to interpret and bring the law to acceptable legal understanding. ${ }^{11}$

The ruling pronounced by the three judge bench (Jj. Mativo, Ngugi and Odunga) set up by the Honorable Chief Justice, David Maraga provoked diverse concerns and interests in the citizenry and its social institutions. The National Super Alliance (NASA) ${ }^{12}$ (Judicial Review No. 378 of 2017) took legal action against the Independent Electoral and Boundary Commission (IEBC) and sought judicial review of the tendering process of the printing of presidential ballot papers, barely 30 days before the general elections scheduled on $8^{\text {th }}$ August 2017.

On the material day, $7^{\text {th }}$ July 2017, the High Court quashed the tender award and ordered IEBC to tender a fresh the printing of the presidential ballot papers due to lack of the constitutional "public participation". ${ }^{13}$ The defense argued that there was no luxury of time for the IEBC to re-tender without interfering with the elections time-table set for $8^{\text {th }}$ August, or rather, the political process. However, the petitioners argued on the strength of the rule of law, ${ }^{14}$ expediency, procedures, precedents, and technicalities, involved in the tendering process that did not, inter alia, observe the rule of "public participation" as quoted thereof:

This case challenges the manner in which the IEBC sourced for a supplier of Election Materials and Ballot papers for the general elections, and, particularly the Presidential Elections scheduled for 8th August 2017. The basic argument by the Applicant is that the IEBC (the Respondent) has failed to comply with important and mandatory Constitutional provisions and has, in addition, misapplied important statutory provisions in the Public Procurement and Disposal Act (hereinafter "PPAD Act"). At the core of its complaint, the Applicant seeks the quashing of the decision by the IEBC to award the tender for the printing of Election Materials and Ballot Papers for the Presidential Elections to the 1st Interested Party. ${ }^{15}$

The major concern of the research in question is to examine the question of legal hermeneutics related to the understanding of the concept of "public participation" as perceived by legal authorities concerned with the administration of justice.

In order to do this, the following research examines the locus standi of the matter before the court and interpretation verbatim of public participation. The following research questions both the legality and legitimacy of the ruling. Did the judges err in their judicial review by quashing the tender and ordering the defendant to

\footnotetext{
${ }^{9}$ Legal Hermeneutics Pdf - Google Search' <https://www.google.com/\#q=legal+hermeneutics+pdf> [accessed 13 July 2017].

${ }^{10}$ B. Beinart, 'The Rule of Law', Acta Juridica, 1962 (1962), 99.

${ }^{11}$ Iain Currie, 'Rule of Law', Annual Survey of South African Law, 1999 (1999), 33.

${ }^{12 ‘}$ Kenya Law Cases Database' <http://kenyalaw.org/caselaw/> [accessed 12 July 2017].

${ }^{13}$ C Court Orders IEBC to Tender Afresh Printing of Presidential Ballot Papers » Capital News', Capital News, 2017 <https://www.capitalfm. co.ke/news/2017/07/court-orders-iebc-tender-afresh-printing-presidential-ballot-papers/> [accessed 12 July 2017].

${ }^{14}$ Judicial Review 378 of 2017 - Kenya Law' <http://kenyalaw.org/caselaw/cases/view/138205/index.php?id=3479> [accessed 12 July 2017]. ${ }^{15 ‘}$ Kenya Law Cases Database’.
} 
The Problem of Legal Hermeneutic in Kenya Concerning the Entrenched Concept of "Public Participation" And the Transformative Public Sphere Reflected in Judicial Review No. 378 of 2017

re-tender the printing of presidential ballot papers? Do the politicians have justified ground to make public utterances accusing the judiciary for lack of impartiality in their judgment? Do the politicians make sense to ignore the interpretation of the meaning of the public participation articulated in the public procurement and assets disposal Act which fleshes the constitution? Is there justification to ignore the rule of law and reduce the judgment to political and non legal forces?

Therefore, it is appropriate to make rational inquiry into the legal methodology that the judiciary follows while interpreting the law. According to Rawls this is the background justice which deals with ambivalences in the administrative justice. ${ }^{16}$ Such background justice is needed for a well ordered society where advantages of power and resources can be divided and distributed fairly. ${ }^{17}$

The process of interpreting and understanding the law one must take into account gnoseology, as theory of knowledge (sentient experience, reason and intuition), ${ }^{18}$ semiotics (psychology of law, form of legal emotions and legal symbols), dialect (any legal dispute represents a conflict of fundamental principles of law which cannot be resolved within the framework of these principles since they point at different directions - conflict of values, anthropological aspect of law - taking into consideration social life of people in a given social context, axiological aspect - a chain of societal values that people have set up to guide them, dialogical aspect of law- the dialogue between the interpreter and the interpreted - the interpretation of the legal text takes into account the creator of the text, conflictological aspect of law - legal hermeneutics is about finding solution to social conflict, and phenomenological aspect of law - the law is a phenomenon of social and human consciousness - focus is not only on the existence but the substance of law). ${ }^{19}$

Before evaluating the issues of legal hermeneutics, it is very necessary to look at some key semantic issues involved in this research.

\section{SEMANTIC ISSUES}

\section{A South African Constitutional Court held as follows}

The phrase "facilitate public involvement" is a broad concept, which relates to the duty to ensure public participation in the law-making process. The key words in this phrase are "facilitate" and "involvement". To "facilitate" means to "make easy or easier", "promote" or "help forward". The phrase "public involvement" is commonly used to describe the process of allowing the public to participate in the decision-making process. The dictionary definition of "involve" includes to "bring a person into a matter" while participation is defined as "(a) taking part with others (in an action or matter); ...the active involvement of members of a community or organization in decisions which affect them". According to their plain and ordinary meaning, the words public involvement or public participation refer to the process by which the public participates in something...it is clear and I must state so, that it is impossible to define the forms of facilitating appropriate degree of public participation. To my mind, so long as members of the public are accorded a reasonable opportunity to know about the issues at hand and make known their contribution and say on such issues, then it is possible to say that there was public participation.".20

Legal interpretation of "Public Participation" is still problematic. The above citation from the case law does not actually provide the semantic definition and interpretation of public participation. It instead, defines public participation by saying it is the process in which the public participates in the process a factor that lacks persuasive evidence.

\footnotetext{
${ }^{16}$ Khan.

${ }^{17}$ Khan.

${ }^{18}$ 'Legal Hermeneutics Pdf - Google Search'.

${ }^{19 ‘}$ Legal Hermeneutics Pdf - Google Search'.

20 'Judicial Review 378 of 2017 - Kenya Law'.
}

American Research Journal of Humanities and Social Sciences 
The Problem of Legal Hermeneutic in Kenya Concerning the Entrenched Concept of "Public Participation" And the Transformative Public Sphere Reflected in Judicial Review No. 378 of 2017

However, the case in question explains in part that public participation is the engagement with the public in what is to be expected (outcome). It allows the communities to express concerns, fears and even to make demands. ${ }^{21}$ However, this kind of definition also considers the integral meaning of democracy in terms of the legitimacy of the decision making process particularly in the electoral laws.

Public Procurement and Assets Disposal Act at Section 103(1) indicates that awarding of tender or any public contract must adhere to the rules of competition and those of the constitutional provision 227(1) which rules that State organs, while awarding any contract for goods or services, shall do so in accordance with the system that is fair, equitable, transparent, competitive and cost-effective. ${ }^{22}$

Failure to comply with the above set-up values shall raise questions of free, fair, equitable, transparent, competitive and credible electoral process. It is in this rationalization that the petitioner has decided to take legal action against the respondent. Arguably, the IEBC could have done better if it had fulfilled those values and principles which are articulated in the constitution under Art. 227(1). The petitioned would have demonstrated that proper engagement of the public in the process and lawful mechanism were followed to the letter.

The ruling pronounced by the three bench judges, Justices Joel Ngugi, John Mativo and George Odunga of the Nairobi High Court orders as follows:

We hereby issue an order of certiorari removing into this Court for the purposes of being quashed the decision of the Independent Electoral and Boundaries Commission (IEBC) awarding the tender for the printing of election materials including ballot papers for the Presidential elections scheduled for 8th August 2017 to the 1st Interested Party herein which decision is hereby quashed. ${ }^{23}$

It is this ruling that has provoked public criticism and more concern about the semantic meaning of the concept of "public participation". Bearing in mind the provisions of the Constitution at Article 23 and section 11 of the Fair Administrative Action Act, 2015 both of which give the Court jurisdiction and wide latitude to grant appropriate relief, the orders we deem appropriate in the circumstances of this case ${ }^{24}$.

\section{SEarch for Meaning of Public Participation}

Rowe and Frewer ${ }^{25}$, in their analysis on the methods of public participation, make it clear that it is involvement or engagement of the public in policy and decision making. However, other authors purport that numerous definitions of the concept "participation" can be found. Participation is contextual. Local participation differs from non-local participation. Even at local level participation varies in type, level of intensity, extent, and frequency. However, in history, people's participation has been ideological basis for democratic society. ${ }^{26}$

By and large, the Republic of Kenya as a state has been the real protagonist of participation whle the society at large lived happily under paternalism. ${ }^{27}$ This narrative has since changed by the new constitution in 2010 . The constitution insists on public participation as the state had not fulfilled most of the expectations of the people and the active participation, therefore, became a mandatory rule. It was felt that the state, vis-à-vis, the government was too much removed from the people and the people developed their own notion of "participation" or rather, participatory system. When the state failed to meet the aspirations and expectations of the people, the idea community came in.

\footnotetext{
${ }^{21}$ Judicial Review 378 of 2017 - Kenya Law'.

${ }^{22}$ 'Judicial Review 378 of 2017 - Kenya Law'.

${ }^{23}$ Judicial Review 378 of 2017 - Kenya Law'.

24'Judicial Review 378 of 2017 - Kenya Law'.

${ }^{25}$ Gene Rowe and Lynn J. Frewer, 'Public Participation Methods: A Framework for Evaluation', Science, Technology, \& Human Values, 25.1 (2000), 3-29.

${ }^{26} J a n$ Servaes, Thomas L. Jacobson, and Shirley A. White, Participatory Communication for Social Change (SAGE, 1996). ${ }^{27}$ Servaes, Jacobson, and White.
} 
The Problem of Legal Hermeneutic in Kenya Concerning the Entrenched Concept of "Public Participation" And the Transformative Public Sphere Reflected in Judicial Review No. 378 of 2017

However still, Kenya's constitutional spirit has so much to do with the Western culture and ideologies, particularly, that of the United States of America. George E. Fellows makes it explicitly clear that the nature of any people's constitution must depend very greatly on the nature and traditions of that people. ${ }^{28}$ Instead, a community self-managed spirit in the United States has been adopted in the Kenyan system to mean that, people at the grassroot level, or what is popularly known in Kenya as Wanjiku, must not only participate in decision making, but must be seen to participate for the needed social change process. ${ }^{29}$ However, good it is for Kenya to benchmark with the USA, the need for a people based constitution is still ideal.

So, to ensure that the general elections are free, fair, transparent and credible, the IEBC must not be seen to be biased or partisan in any way in making vital decisions especially, the printing of the presidential ballot papers. It is to avoid nasty speculations that persons of interest may print extra ballot papers that would be stuffed into the boxes to inflate the numbers of the preferred candidate. Such flawed elections have occurred in Kenya in the previous elections, especially in 2007. A call for greater public involvement is therefore, obvious and the court intervention has exactly done what was expected within the conception of the rule of law and constitutionalism ${ }^{30}$ which Kenya is craving for.

There are varieties of public participation procedures that aim to consult and involve the public. ${ }^{31}$ This means, there is no one method of public participation. There are several methods that people have approved as the best interpretation of public participation. This includes public hearing to consensus hearings. However, it is also necessary to consider the empirical quality of such methods and procedures.

Official Gazette of the Republic of Kenya is one of the methods or means of communicating information to the "public" consumers. IEBC, as any other government agency, is known for its vigorous use of print media to communicate with the public. However, this traditional method faces its own challenges. The participatory communication theory does not only mean that the government gives the information to the public. There is no participation of the public as much as the understanding of the participatory theory is concerned. It is mono directional instead of multi directional. It is A giving the information to B, yet B is not expected to share its input to make the outcome be participatory knowledge.

Public Participation, as explained by experts means that, both " $\mathrm{A}$ " and "B" must meaningfully engage in looking for shared ideas or rather, the inclusion of the public views to avoid being partisan. ${ }^{32}$ It cannot be only publishing information in the official gazette. That would work well in the olden system in which it was the State doing it and the society expected to believe and act. ${ }^{33}$

In public participation theory, the quality of the output in this exercise should bring expected social change. It should transform the society in a positive manner. It should build more confidence of the public towards public affairs of the state. It is the notion underlying democratization, constitutionalism and the rule of law in the modern systems.

Kenya is part of the Third World countries whose notion of democracy is in the process of progress. There is the idea of centralization of state operations on the government and the idea of decentralization of such operations. In other words, there is critical opposition of Up-Down approach and more inclination to Bottom-Up or more interactive approach to social change. The meaning of public participation in the work of Wojciech Sadurski on Joseph $\mathrm{Raz}^{34}$ therefore, is intertwined with the classic notion of "democracy" as the rule of the people, by

${ }^{28}$ Fellows.

${ }^{29}$ Servaes, Jacobson, and White.

${ }^{30}$ Fellows.

${ }^{31}$ Rowe and Frewer.

${ }^{32}$ Beinart.

${ }^{33}$ Servaes, Jacobson, and White.

${ }^{34 ‘}$ Raz on Representative Democracy - Google Search' <https://www.google.com/\#q=Raz+on+representative+democracy>[ac cessed 14 July 2017].

American Research Journal of Humanities and Social Sciences Page 5 
The Problem of Legal Hermeneutic in Kenya Concerning the Entrenched Concept of "Public Participation" And the Transformative Public Sphere Reflected in Judicial Review No. 378 of 2017

the people and with the people. The same notion is reflected in Article 1 of the Constitution which states, the sovereignty of the constitution is with the people of Kenya. It is the empowerment of the citizenry other than the empowerment of the government. In this process, the government must be seen as a servant of the people as opposed to the master of the people. Government operations must be seen to be services to the public other than orders and decrees,

Other studies have shown that concept mapping is necessary in conducting critical review of development participation literature to sort out main concepts and relationships of concepts. In general understanding popular, local participation, and the means of enhancing it, are necessary elements in successful development efforts around the conception of democracy and state authroity. ${ }^{35}$ Underlying concept of public participation ought to be the citizen control, vis-à-vis, the people's empowerment control public decision making process.

Pseudo-participation refers to people's participation in any public process in which the projects and decision making power rests with planners (CEO), administrators and the communities' elite. The participation of the people is reduced to listening to what is being planned for them and what would be done unto them. For instance, public participation in the legislative bodies consider people sitting in the public galleries or speakers galleries to here the legislative proceedings. This is pseudo-participation that limits the participatory communication and may not be valid. Legitimate authority and the conception of the service must be interpreted and understood in the validity of the law as been the concern of legal scholars.

Ronald Dworkin, Joseph Raz and John Finnis have all struggled with the conception of obedience of the law enacted by legitimate government in their discussions. However, John Rawls elaborates the representative democracy in his political theory and his publication a theory of justice of 1971 illustrates the question of unfairness in deliberative democracy through representation. ${ }^{36}$

The in-depth analysis of how the concept of participation can be legitimately transformed into action of the public in the decision making process. It also requires a careful observation of communication behavior throughout the process such as knowledge sharing and learning of all participating actors.

The pivotal sub-concepts here are therefore, power and control which facilitate the understanding of the diversities of expectations and anticipated outcomes of people's participation. ${ }^{37}$ It is important to make enquiry into the stakeholders' participation. Who are the stakeholders and how do they participate in the decision making process?

\section{Philosophical Interpretation of the Public Participation}

The Kenya's constitution 2010 provides also for participation through representation or what is referred to as representative democracy. In a transformative structure representation under Art.1(2) of the constitution involves election of the representatives under chapter seven, the representation of the people (electoral system and the process)

The electoral system shall comply with freedom of citizens to exercise their political rights; not more than two thirds of the elective population shall be of the same gender, fair representation of persons of disabilities. The process must be free, fair and transparent. Jurgen Habermas (1964) ${ }^{38}$ in his thinking made it explicitly clear that the public sphere is transforming through pre-conditional structures that including electoral process and the law. ${ }^{39}$ It is a sphere between civil society and the state in which critical public discussion of matters ofgeneral interest is institutionally guaranteed. ${ }^{40}$

\footnotetext{
${ }_{35^{\prime}}$ Raz on Representative Democracy - Google Search'.

${ }^{36}$ 'john Rawls on Democracy - Google Search' <https://www.google.com/\#q=john+rawls+on+democracy> [accessed 14 July 2017].

${ }^{37}$ 'Deshler and Sock 1985 - Google Search' <https://www.google.com/\#q=deshler+and+sock+1985> [accessed 12 July 2017].

${ }^{38}$ Calhoun.

${ }^{39}$ Jürgen Habermas, Sara Lennox, and Frank Lennox, The Public Sphere: An Encyclopedia Article (1964), New German Critique, 1974, 49-55. ${ }^{40}$ Calhoun.
} 
The Problem of Legal Hermeneutic in Kenya Concerning the Entrenched Concept of "Public Participation" And the Transformative Public Sphere Reflected in Judicial Review No. 378 of 2017

The understanding of the public sphere is what explains the use of public in what other cultures would call a house of representatives. In democratic theories, representation is used as a way of involving the rest of the public in a smaller group of representatives. The Republic of Kenya has adopted representative democracy through free and fair elections.

General belief is that, free, fair and credible elections, the elected would represent the will of the electorates in matters of public and general interest. Rawls sees this as the deliberative democracy which should translate into more legitimacy in his political liberalism theory. ${ }^{41}$ In the article of Angela D. White, Rawls argues that political decisions are valid in so as they are made in a process that allows citizens to exchange reasons that are respectful and moral. ${ }^{42}$ The understanding of the public sphere by classical thinkers is that, all matters related to the general interest of the public belong to the public sphere as opposed to private sphere.

Even if Habermas theory ${ }^{43}$ of the transformative public sphere has been very influential, it has not missed some important intellectual criticism. Representative democracy has its serious challenges as well. Dialectically, some representatives do not actually represent the will of the electorates. In this case, the elected are given power which they do not utilize for the benefit of the common good but rather, individual good. Habermas account seeks to remedy this doubt by embracing public opinion through media, public participation in matters of general and common interest, and transformative structures that are necessary for social change. ${ }^{44}$

By the public sphere we mean first of all a realm of our social life in which something approaching public opinion can be formed. ${ }^{45}$ In the same purview it is right to relate public participation to public opinion in which access is guaranteed to all citizens. In such manner, the IEBC was not supposed to handle the tender for printing presidential ballot paper as a private affairs but, rather, public affair. It is in this contention that the meaning of "public" relates to what Roman jurists referred to as res repubblica as opposed to res privata.

By such definition, the public sphere theory of Habermas indicates clearly that the citizens must have access to information and also give information. ${ }^{46}$ In the theory of participatory communication the proper understanding of public participation can then be justified by wide public consultations, sharing of ideas, interactions, collection of views and in a deliberative manner ${ }^{47}$ Radio, Print, television and social media are all types of public sphere par excellence. The IEBC could as well utilize such communication tools and engage more with the public in the alleged flawed tendering process.

Some pragmatic risks can be inferred from any form of failure to involve the public sphere in matters of general public interest such as general elections. First, the citizens shall lose confidence in the electoral body which is obligated to conduct free, fair and transparent elections. It is in this contention that one can argue that the electoral process lacks legitimacy and support of the majority in a democratic set-up. For instance, the expression public opinion means that the populace is invited to interact and share views on the matters related to public affairs. Such interaction involves criticism ${ }^{48}$ and control by the public as in informal Bunge ya wanainchi (Parliament of the people) where ideas are mutually shared with the general public and in formal general elections of the ruling structure in form of a state. ${ }^{49}$ Regulations demanding that certain proceedings must be made public, is therefore, in line with Habermas concept of public sphere published in the Encyclopedia in 1964.

\footnotetext{
${ }^{41}$ 'John Rawls on Democracy - Google Search'.

${ }^{42}$ 'Raz on Representative Democracy - Google Search'.

${ }^{43}$ Habermas, Lennox, and Lennox.

${ }^{44}$ Calhoun.

${ }^{45}$ Habermas, Lennox, and Lennox.

${ }^{46}$ 'Raz on Representative Democracy - Google Search'.

${ }^{47}$ 'Raz on Representative Democracy - Google Search'.

${ }^{48}$ Habermas, Lennox, and Lennox.

${ }^{49}$ Habermas, Lennox, and Lennox.
}

American Research Journal of Humanities and Social Sciences 
The Problem of Legal Hermeneutic in Kenya Concerning the Entrenched Concept of "Public Participation" And the Transformative Public Sphere Reflected in Judicial Review No. 378 of 2017

Referring to the Judicial Review No. 378 of $2017^{50}$ prominent questions were raised concerning other elective positions that were spared from the ruling. Only the Presidency is the main public figure whose election involves all citizens as compared to other positions. The presidency holds state authority ${ }^{51}$ which, in the reading of Habermas, is equal to public authority of the highest rank. It is, therefore, agreeable for the case on public participation to concern mostly the highest political position first with the belief that such decision shall form precedent for future considerations and other political positions.

\section{Legal Interpretation of Public Participation}

Interpretation of the law is the work of both legislator and the judge. The legislator (representing the will of the electorates) makes the law while the judge (representing the administration of justice) ought to interpret and understand it. ${ }^{52}$ What follows all this is the methodology informing the interpretation of the law and making the interpretation legitimate. ${ }^{53}$

The argument seeking to throw some doubt about the interpretation should take into account the province of law. The law does not operate in a vacuum but in politically charged social set-ups. Remember that the legislator's duty is to make the law but it is the onus of the judge to interpret, understand and apply it in the administration of justice. This takes into consideration a number of issues as explained in the legal hermeneutics. For instance, it is not only the existence of the law that matters, but its substance. It is the duty of the honourable judge to interpret and understand what the honourable legislator actually mean by the language of the law. ${ }^{54}$

This comes with some substantial challenges. It is undeniable that there could be some flaws in the interpretation and the law making process. The appellate court is meant to fill in the gap in the interpretation and understanding of the law by trial judge. Often, in the judicial review proceedings (the tribunal) it is found out that the judge dismisses certain type of law due to lack of its legal meaning through interpretation process. ${ }^{55}$ The appeal judges shall have the judgment for another thorough review and scrutiny. If found that there were some flaws, lack of impartiality or both, then the appeal court can quash the ruling order for a fresh trial. The understanding of this judicial process is to ensure that the parties under litigation are satisfied by the outcome of the court. It is by doing this, the judiciary shall build more confidence of the public and to ensure that justice is seen to be done.

The legality of legal hermeneutics ${ }^{56}$ is anchored on the powers given to the court by the constitution. It simply means that the court is acting within the law and the constitution while making judgment over a case before it. The law demonstrates its authority through the work of court and such authority must emanate from the constitution and the law.

Another challenge is based on the mutual relationship between the legal hermeneutics and hermeneutic understanding of the problem brought before court for judicial review. There must be some level of foundation of legal hermeneutic. The understand of the law should consider areas of the law and natural justice ${ }^{57}$ Mutual understanding and the understanding of public participation within a hermeneutic community must equally take into account all areas related to the jurisprudence or philosophy of law. ${ }^{58}$

Without the understanding of the legal hermeneutics it is difficult to translate law into real art as the Romans would claim: the art of good and justice (jus et ars boni et aequo) ${ }^{59}$ It is in this perspective that one should consider the critiques related to any court judgment and ruling based on the public participation claim.

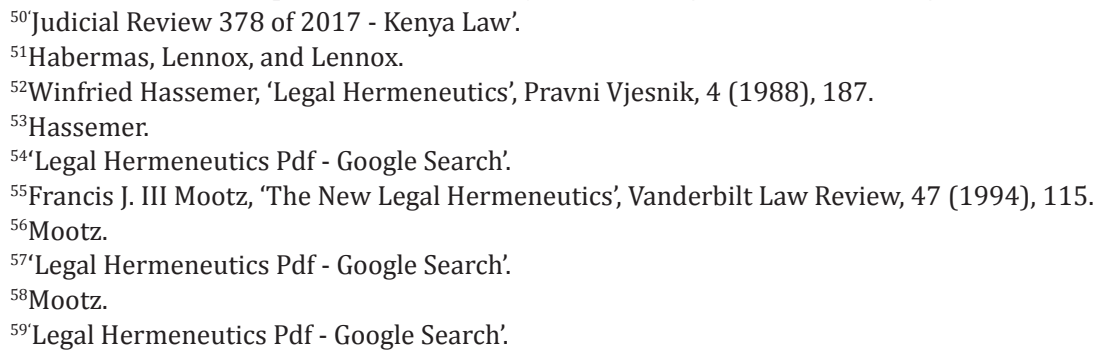

American Research Journal of Humanities and Social Sciences Page 8 
The Problem of Legal Hermeneutic in Kenya Concerning the Entrenched Concept of "Public Participation" And the Transformative Public Sphere Reflected in Judicial Review No. 378 of 2017

\section{Critique of Modern Understanding of Public Participation}

Article 1(1) All sovereign power belongs to the people of Kenya and shall be exercised only in accordance with this constitution. Sub-Article (2) The people may exercise their sovereign power either directly or through their democratically elected representatives. ${ }^{60}$

It would be misleading to believe that such representative (deliberative) democracies are the panacea for development without interpreting it. ${ }^{61}$ Participatory communication par se is more of an illusion rather than a factual idea that would automatically lead to the expectations of the people in a given particular society. ${ }^{62}$ The concept of participation through representatives can as well become a mechanism of manipulating and taking the advantage of the ignorance of the general populace.

The price people have to pay in taking part in the participation narrative is always overlooked by the interpreters. It is often assumed that the villagers have nothing better to do with their time. In the consequence, the Kenya's public has developed the narrative which says, "the elected member (representative) shall speak and read the law on the behalf of the electorates". How accurate this legal provision is, is a question of legal hermeneutics.

The elected representatives are individuals who are also politicians. A politician plays politics, that is, his concern in the society is about the issues of power, interests and making decisions for the people to follow. His or her role is to provide leadership and offer avenues for overseeing elements of mismanagement, make policies and laws that would steer the state to the achievement of its ultimate values and ideals.

Out of sentient experience, several politically elected individuals do not carry out the representation duty but they act on their personal vested interests such as claiming sitting allowances. This contradicts Rawls' theory of deliberative democracy and puts governance in focus. ${ }^{63}$ What sense does it make for an elected member of the National Assembly, the Senate, and County Assemblies to claim an entitlement to sitting allowances if they are employed by the tax payers to sit and legislate and deliberate on public issues? Would it not be a double standard to receive salary and at the same time make claims for sitting? Is sitting in the house separate from the job one is paid for? Only the legal hermeneutics can shade light on this conflictological ${ }^{64}$ issue. However, John Rawls interprets justice as basic fairness in a multidimensional interactions between humans and their institutions. ${ }^{65}$

Kenya's politicians are the best paid citizens according to the pay group and categories. Their allowances are not subjected to taxation while they enact Bills to enable them access hefty packages and security as compared to other workers. It is in the sense of setting a balance in wages that the constitution established Salary and Remuneration Commission whose mandate is to foresee that there is socio-economic balance in remunerating public servants. The $11^{\text {th }}$ Parliament defied the recommendations of the commission and went ahead to pass Bills to favour their income. White sees this in light of Rawls theory of justice: according to Rawls, is "background justice", which is needed for a well ordered society where advantages of power and resources can be divided and distributed fairly. Upholding this fairness principle would involve limits on power, preventing excessive concentration and resulting misuse by individuals, groups, associations and institutions. ${ }^{66}$ Public participation is an ideal principle that shall limit the excesses and abuse of office.

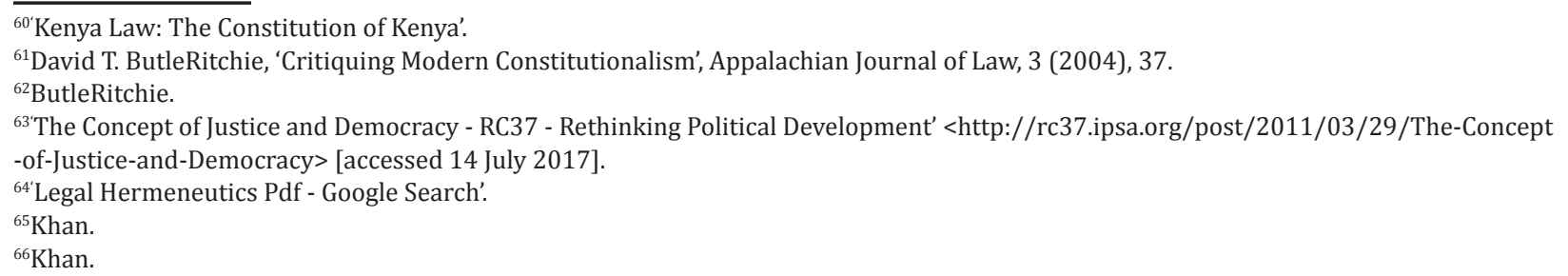


The Problem of Legal Hermeneutic in Kenya Concerning the Entrenched Concept of "Public Participation" And the Transformative Public Sphere Reflected in Judicial Review No. 378 of 2017

Despite the establishment of the SRC, Kenyan legislators still can use their constitutional power to sabotage the passing of bills including the budget to arm-twist the executive which is opposed to the understanding of constitutionalism. ${ }^{67}$ Constitutionalism is about good governance. It questions whether the government and its officers conduct themselves in the constitutional and lawful way. ${ }^{68}$

Is the concept of participation, therefore, legitimate? Through the democratically elected representatives the concept of participation ought to work with conditions of public participaiton. ${ }^{69}$ Representatives that have not met the expectations of the electorates may not expect another chance from the people who elected them. This should be the only punishment. Whoever feels that he or she should be re-elected shall act according to the expectations and satisfaction of the public. However, it is wise to believe that such concepts of public participation, democratization, constitutionalism and the rule of law ${ }^{70}$ tend to mature slowly in the society due to scarce interpretation and understanding of the concept. One should not expect population to be mature over night. People learn out of experience and sacrifice.

Political communities must create mutual understanding on public participation and prove deep commitment of the leadership to justice. Governance must ensure human rights, due process of law and fairness. ${ }^{71}$ Rawls envisions this as a form of social contract. ${ }^{72}$ Citizens and their institution create common ground of understanding and cooperation as found in the work of Angela D. White. ${ }^{73}$ It is in line with what Prof. George Saitoti had referred to while saying, "there comes a time when the nation is more important than an individual". ${ }^{74}$

\section{The Rule of Law Versus Public Participation litigation}

It is also misleading to think that democratization process can is an event rather than an antagonizing process that violates the Bill of Rights. ${ }^{75}$ Any sort of democratization must have some control mechanism in place in order to regulate and control it. The best societal tool to ensure that social change is controlled is the application of the law by the court. It does not mean that law is always right. It does not mean that the law is always good at least for all people. It is in this moral sense one can conveniently argue that the court is justified to interpret and understand the law within the hermeneutic methodology. In the same light of thought, the constitution under Art. 47(1) illustrates as follows: Every person has the right to administrative action that is expeditious, efficient, lawful, reasonable and procedurally fair. ${ }^{76}$

The fact that all disputes must be settled in court is opposed to arbitrariness and the rule of man., The emphasis is the rule of law, constitutionalism and human rights. The three principles lead to democratization of the entire system. The court as the law enforcing authority cannot do anything less than applying the enacted law, the constitution and principles of precedent in making a ruling. ${ }^{77}$ It is by doing so that legal hermeneutics in interpreting and understanding the concept of public participation become indispensable.

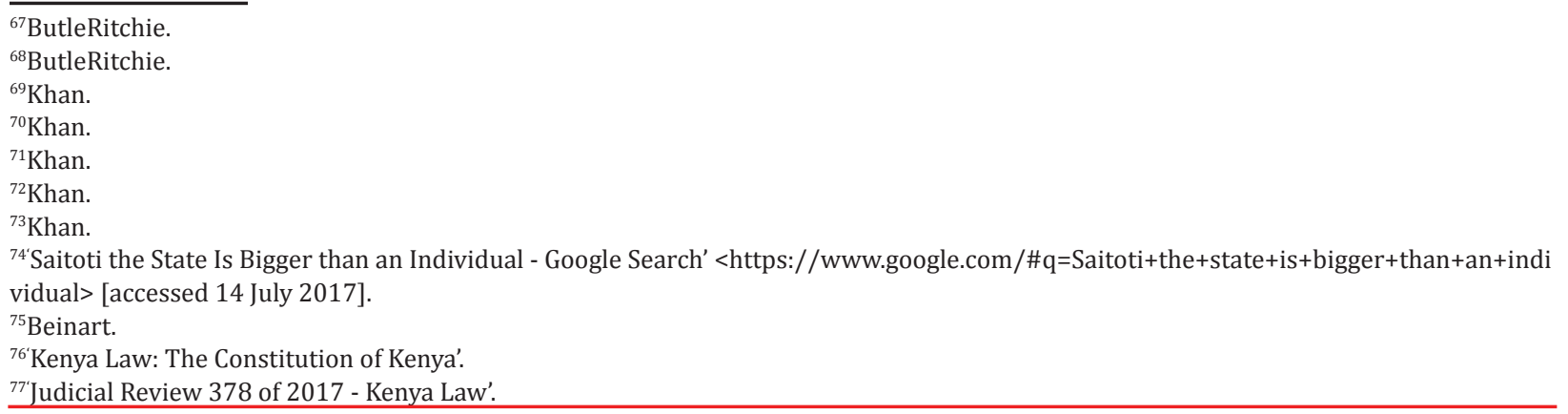

American Research Journal of Humanities and Social Sciences 
The Problem of Legal Hermeneutic in Kenya Concerning the Entrenched Concept of "Public Participation" And the Transformative Public Sphere Reflected in Judicial Review No. 378 of 2017

Prof. Ian Currie of the Cape Town Univeristy has clearly cited this section in his work on the rule of law:

It seems central to the conception of our constitutional order that the legislature and executive in every sphere are constrained by the principle that they may exercise no power and perform no function beyond that conferred upon them by law. At least in this sense, then, the principle of legality is implied within the terms of the interim Constitution. Whether the principle of the rule of law has greater content than the principle of legality is not necessary for us to decide here. We need merely hold that fundamental to the interim Constitution is a principle of legality. ${ }^{78}$

The opposite of the rule of law is the rule of men in which arbitrariness is the order of the day. Constitutionalism is very emphatic on the rule of law, that is, seeking remedy in the court of law other than taking law into one's hands. By doing so, the court must pursue a value-neutral procedural requirements along the lines of the common law ultra-vires doctrines. ${ }^{79}$

Legal hermeneutics therefore insists on both legal and non legal doctrines while interpreting and understanding the law is not committing illegality in interpreting the law but is offering holistic consideration of the judicial reasoning thereto. The rationale is to avoid biases while making a ruling on such politically charged judicial review petition.

\section{METHOdS OF PUBLIC PARTICIPATION}

Whether local or public participation there must be some level of understanding when it comes to methods that are acceptable. In regard to this, it is necessary to look at scientific techniques and criteria that would make public participation be what it ought to be. Such things as seeking public opinion, utilizing questionnaires in collecting data information, selecting groups to represent communities and at whose expense must be taken into consideration. Methods must also explain how such information shall be shared among the participants and the general public. Kenya must generate a framework for public participation besides the constitutional and statutory provisions. There must be coherent policy document that explains the methods to be followed in order to get credible outcome.

As has been reiterated before, the involvement of the public in decision making ${ }^{80}$ in matters of public interest is a question of the nature and history of the people as prescribed by the constitution. Every society has its own way of perceiving public participation and, in order to be, fair, Kenya has considered organizations and institutions in the public participations. Both private and public sectors have been considered mutually. However, higher stake is with the civil societies and churches or faith based organizations.

In an inclusive approach, it is believed that political parties, churches, civil society and other public agencies are the best methods to define public participation. The rationale behind this belief is related to the fact that each of such stakeholder group has got followers. For instance, political parties have got their members, followers, adherents and sympathizers in the political divide. Similarly, faith organizations have got their own members, followers, believers and those who have faith in their ideologies. The same to other public agencies and private sectors. This narrative holds that almost every member of the public belongs to any or most of such entities.

However, the participation must also take into account the opinions from such stakeholders and how such opinions were considered during the evaluation and samplings. It is in this sense that a framework of methods is necessary. There must be a criterion that is empirically proven which authorities shall use to ensure adequate public participation.

\footnotetext{
${ }^{78}$ Beinart.

${ }^{79}$ Beinart.

${ }^{80}$ Judicial Review 378 of 2017 - Kenya Law’.
}

American Research Journal of Humanities and Social Sciences Page 11 
The Problem of Legal Hermeneutic in Kenya Concerning the Entrenched Concept of "Public Participation" And the Transformative Public Sphere Reflected in Judicial Review No. 378 of 2017

The question that follows, has public input been incorporated in any decision that affects the public? Were there adequate level of consultation on the matter? Was enough time given for stakeholders to share their views?

Such framework must also take into account some budget. Participation without financial involvement is also unpractical and destined to fail. Expecting a member or members of the public to dedicate their time and money for a public event for the sake of public participation would be an assumption. What people often ask is, how will this participation benefit me? The sense of the "common good" is anticipated by immediate needs of individuals and groups.

\section{PRE-REQUISITES FOR PUBLIC PARTICIPATION}

\section{Civic Education81}

First and foremost the public must be educated and properly trained to understand what public participation is all about and what it means to them.

\section{Funding of public participation initiatives (financial strategy)}

Voluntarism is an assumption that does not work well in the Third World countries. When public participation is construed as persons who are willing to volunteer in the exercise then it ruins the meaning. The reaction of the people is usually to avoid serving for free. This is also exacerbated by materialism and capitalism that make people value paid jobs other than volunteering for the sake of the common good.

In order for public participation effort to be effective, there must be some level of financial commitment to appreciate the participants.

\section{Dissemination methods (participatory communication) media and others}

Mass communication is the best method for disseminating the concept of public participation in any public undertaking. What medium do the authorities use to ensure that as many as possible members of the public get the information? It matters so much to build wider awareness in the public of what is about to occur. Such information should reach the public before and not after the decision has been made.

\section{Stakeholders balancing as per regions or counties or wards}

When we speak about the public one must consider the geographical representation. If it is a matter of national importance such as presidential ballot paper printing, then the authorities must cast their nets wider and ensure that the whole nation is involved. Such process shall require some structures and framework.

\section{Time-frame and Activities}

It would be wrong to conclude that time is not of issue here. Every plan must have time frame. This should also take into account any eventual court petition that may as well claim some more time before the case is heard and determined. The failure to plan is the failure to succeed in public participation as a project. So many issues may emerge that may change the entire time-frame.

\section{Feedback or Monitoring and Evaluations}

Public participation must as well take into account the monitoring and evaluation criteria. There must be some sense of monitoring and reporting. How will the stakeholders know if their concern or inputs are considered or not? Who shall be monitoring the quality of such inputs before the final decision is taken?

\section{Code of Conduct}

There are ethical issues that we cannot miss in this research. The behavior of members is critical in public participation. Some people may take bribe to support a decision due to ideological convictions or vested interest. It is common in political processes and in such matter, ethics is vital. The stakeholders must men and

81‘Kluwer Law International Journal Library Search - HeinOnline.Org'. 
The Problem of Legal Hermeneutic in Kenya Concerning the Entrenched Concept of "Public Participation" And the Transformative Public Sphere Reflected in Judicial Review No. 378 of 2017

women of integrity and those who are not influenced by lobby groups and political affiliations. Such utilization of ethical principles is quite ideal for Kenya.

\section{Secretariat (organizational strategy)}

Public participation should not be expected to function in a vacuum. There must be some level of coordination. A secretariat or organization must be put in place. Often there must be a technical committee concerned with public participation issues.

\section{Benchmarking}

Finally, there must be benchmarking. It is not realistic to speak of public participation without comparing one context with the other. It is in this scale that public participation can take effect. For instance, IEBC can benchmark with another country before coming up with its own criteria of public participation. Such method should build more credibility in the system.

\section{Political Rights in KenYa}

The Bill of Rights in the constitution of Kenya under Art. 38(2) illustrates that every citizen has the right to free, fair and regular elections based on universal suffrage...the use of the terminologies free, fair and regular require legal hermeneutics for their interpretation and better understanding by the court of law. ${ }^{82}$

State agencies such as IEBC are all under obligation to comply with the constitutional provisions and defend its integrity. It is in this manner, the decision of the High Court was upheld by the petitioners. However, there is a window for the aggrieved party to resort to the Court of Appeal that shall review the decision made by the trial judges and make its decision.

\section{CONCLUSIVE REMARKS}

Building the participative society is a process and not an event. It can take a society many years to implement the concept of public participation. However, the best way forward is constitutionalism, rule of law, and empowering the people through building faith in the public institutions. Parliament, Government, Court or rather, the legislature, the executive and the judiciary must all play their role. There must be professionalism, integrity, and faithfulness in the entire social system in order for social change to occur. It is not a question of who won and who lost the case in court, but rather, whether there is consensus on procedures, rule of law and expediency. The due diligence is the criterion and guideline for state actors and those who provide leadership in the rank of presidency and the opposition. It should not appear that the same leadership is putting obstructing the wheels of justice or purporting to shade bad light in the public institutions. Instead, the presidency must abide by the law and promote justice ${ }^{83}$ by all means. ${ }^{84}$

It is recommended that the IEBC must promote public participation and build more confidence in the electoral process. It is in this manner that the people would accept and agree with the outcomes of elections. The failure to promote fairness, freedom and credibility of the process is the recipe for chaos that can threaten peace and security of the people in a pluralistic social set up such as Kenya.

Public participation is a socio-cultural process that requires change of attitude and perceptions ${ }^{85}$ It is not easy to assume that public participation is only the question of publication but it must be participatory communication in the making.

\footnotetext{
${ }^{82}$ Judicial Review 378 of 2017 - Kenya Law'.

${ }^{83}$ Khan.

${ }^{84}$ Antonin Cohen, 'Constitutionalism without Constitution: Transnational Elites between Political Mobilization and Legal Expertise in the Making of a Constitution for Europe (1940s-1960s)', Law and Social Inquiry, 32 (2007), 109.

${ }^{85}$ Jürgen Habermas, The Structural Transformation of the Public Sphere: An Inquiry Into a Category of Bourgeois Society (MIT Press, 1991).
}

American Research Journal of Humanities and Social Sciences 
The Problem of Legal Hermeneutic in Kenya Concerning the Entrenched Concept of "Public Participation" And the Transformative Public Sphere Reflected in Judicial Review No. 378 of 2017

In that context the legal system, which for developing countries still carries the baggage of colonialism, must be reformed. Justice in and for Democracy needs a basic structure of society where "main political and social institutions of society fit together into one system of social cooperation, and the way they assign basic rights and duties and regulate the division of advantages that arises from social cooperation over time. ${ }^{86}$

The constitution of Kenya has been described as a progressive and transformative by many constitutional lawyers. The state has its strong institutions that seem to hold the state apparatus together but fails to make main political and social institutions of society fit together into one system of social cooperation as evidenced in the Judicial Review No. 378 of 2017. However, constitutionalism ${ }^{87}$ moves beyond a mere written document. The understanding of constitutionalism is the social structure that enhances increasing public participation in matters affecting the general public such as general elections.

\section{REFERENCES}

Beinart, B., 'The Rule of Law', Acta Juridica, 1962 (1962), 99

ButleRitchie, David T., 'Critiquing Modern Constitutionalism', Appalachian Journal of Law, 3 (2004), 37

Calhoun, Craig J., Habermas and the Public Sphere (MIT press, 1992) <https://books.google.com/books?hl=en\& $\mathrm{lr}=\& \mathrm{id}=5 \mathrm{~F} 8 \mathrm{qjMkoxZ0C} \& \mathrm{oi}=$ fnd \&pg=PR7\&dq=habermas + public + sphere\&ots=muxhD0ZOe9\&sig=ioANQJx p2yiowBJyR4myVKXpG4U> [accessed 14 July 2017]

Cohen, Antonin, 'Constitutionalism without Constitution: Transnational Elites between Political Mobilization and Legal Expertise in the Making of a Constitution for Europe (1940s-1960s)', Law and Social Inquiry, 32 (2007), 109

'Court Orders IEBC to Tender Afresh Printing of Presidential Ballot Papers » Capital News', Capital News, $2017<$ https://www.capitalfm.co.ke/news/2017/07/court-orders-iebc-tender-afresh-printingpresidential-ballot-papers/> [accessed 12 July 2017]

Currie, Iain, 'Rule of Law', Annual Survey of South African Law, 1999 (1999), 33

'Deshler and Sock 1985 - Google Search' <https://www.google.com/\#q=deshler+and+sock+1985> [accessed 12 July 2017]

Fellows, George E., 'Constitutionalism', Maine Law Review, 1 (1908), 122

Habermas, Jürgen, The Structural Transformation of the Public Sphere: An Inquiry Into a Category of Bourgeois Society (MIT Press, 1991)

Habermas, Jürgen, Sara Lennox, and Frank Lennox, 'The Public Sphere: An Encyclopedia Article (1964)', New German Critique, 1974, 49-55

Hassemer, Winfried, 'Legal Hermeneutics', Pravni Vjesnik, 4 (1988), 187

'John Rawls on Democracy - Google Search' <https://www.google.com/\#q=john+rawls+on+democracy> [accessed 14 July 2017]

'Judicial Review 378 of 2017 - Kenya Law' <http://kenyalaw.org/caselaw/cases/view/138205/index. php?id=3479> [accessed 12 July 2017]

'Kenya Law Cases Database' <http://kenyalaw.org/caselaw/> [accessed 12 July 2017]

${ }^{86}$ Khan.

${ }^{87}$ Cohen.

American Research Journal of Humanities and Social Sciences

Page 14 
The Problem of Legal Hermeneutic in Kenya Concerning the Entrenched Concept of "Public Participation" And the Transformative Public Sphere Reflected in Judicial Review No. 378 of 2017

'Kenya Law: The Constitution of Kenya' <http://www.kenyalaw.org/kl/index.php?id=398> [accessed 12 July 2017]

Khan,Zillur R.,'The Concept of Justice and Democracy',2011<http://rc37.ipsa.org/post/2011/03/29/ The-Concept-of-Justice-and-Democracy> [accessed 14 July 2017]

'Kluwer Law International Journal Library Search - HeinOnline.Org' <https://vpn.uonbi.ac.ke/proxy/http/ heinonline.org/HOL/LuceneSearch?terms=public+participation\&collection=kluwer\&searchtype=advance d\&typea=text\&tabfrom $=\&$ submit $=$ Go $>$ [accessed 12 July 2017]

'Legal Hermeneutics Pdf - Google Search' <https://www.google.com/\#q=legal+hermeneutics+pdf> [accessed 13 July 2017]

—<https://www.google.com/\#q=legal+hermeneutics+pdf> [accessed 13 July 2017]

Mootz, Francis J. III, 'The New Legal Hermeneutics', Vanderbilt Law Review, 47 (1994), 115

'Raz on Representative Democracy - Google Search' <https://www.google.com/\#q=Raz+on+representative+de mocracy> [accessed 14 July 2017]

Rowe, Gene, and Lynn J. Frewer, 'Public Participation Methods: A Framework for Evaluation', Science, Technology, \& Human Values, 25 (2000), 3-29

'Saitoti the State Is Bigger than an Individual - Google Search' <https://www.google.com/\#q=Saitoti+the+state +is+bigger+than+an+individual $>$ [accessed 14 July 2017]

Servaes, Jan, Thomas L. Jacobson, and Shirley A. White, Participatory Communication for Social Change (SAGE, 1996)

'The Concept of Justice and Democracy - RC37 - Rethinking Political Development' <http://rc37.ipsa.org/ post/2011/03/29/The-Concept-of-Justice-and-Democracy> [accessed 14 July 2017]

Citation: Dr. Peter Onyango Onyoyo, Justice Joel Ngugi, Justice John Mativo, Justice George Odunga Al-Gurair "The Problem of Legal Hermeneutic in Kenya Concerning the Entrenched Concept of "Public Participation" And the Transformative Public Sphere Reflected in Judicial Review No. 378 of 2017." American Research Journal of Humanities and Social Sciences, vol 3, no. 1, 2017, pp. 1-15.

Copyright (C) 2017 Dr. Peter Onyango Onyoyo, Justice Joel Ngugi, Justice John Mativo, Justice George Odunga Al-Gurair, This is an open access article distributed under the Creative Commons Attribution License, which permits unrestricted use, distribution, and reproduction in any medium, provided the original work is properly cited. 